\title{
Pengaruh Metabolit Tumor Akibat Sindrom Tumor Lisis pada Terjadinya Gagal Ginjal Akut Serta pada Anak
}

\author{
Trie Hariweni
}

\begin{abstract}
Sindrom tumor lisis merupakan triad kelainan metabolik (hiperurisemia, hiperfosfatemia, hiperkalemia) yang sering terjadi pada pasien keganasan akibat sel-sel tumor lisis secara cepat baik secara spontan ataupun karena pengobatan anti kanker. Metabolit tumor (asam urat, fosfor, kalium) semuanya diekskresi oleh ginjal sehingga sering menimbulkan komplikasi pada ginjal. Komplikasi tersering adalah gagal ginjal akut, hal ini memerlukan perhatian yang serius karena lebih mudah dicegah daripada diobati.
\end{abstract}

Kata kunci: sindrom tumor lisis, gagal ginjal akut

(1) ognosis anak yang menderita kanker telah membaik secara dramatis pada beberapa dekade terakhir ini. Seiring dengan kemajuan prognosis tersebut diperlukan adanya pengenalan dan pengobatan terhadap komplikasi yang mungkin timbul pada penyakit keganasan anak, karena beberapa komplikasi ini bersifat darurat dan memerlukan penanganan yang cepat dan tepat. ${ }^{1}$

Gagal ginjal akut (GGA) merupakan komplikasi yang sering dijumpai pada pasien dengan keganasan, ${ }^{1-3}$ dan memerlukan perhatian yang serius karena lebih mudah dicegah. ${ }^{4}$ Selain itu adanya gangguan fungsi ginjal mungkin merupakan faktor paling penting yang menentukan kelangsungan hidup pasien, ${ }^{5}$ karena ginjal merupakan organ yang berfungsi sebagai alat ekskresi utama dan menerima hampir $25 \%$ dari seluruh aliran darah. ${ }^{6,7}$ Besarnya aliran darah ke ginjal ini menyebabkan keterpaparan ginjal terhadap bahan /zat yang beredar dalam sirkulasi cukup tinggi.

\footnotetext{
Alamat korespondensi:

Dr. Trie Hariweni

Bagian Ilmu Kesehatan Anak. FK-USU/RS H Adam Malik, Medan.

Jl. Bunga Lau no. 17, Medan 20136.

Telepon: 061-836 0405, 836 0143. Fax. 061-836 1721.
}

Akibatnya, bahan-bahan yang bersifat toksik akan mudah menyebabkan kerusakan jaringan ginjal dalam bentuk perubahan struktur dan fungsi ginjal. ${ }^{7}$

Sindrom tumor lisis merupakan triad kelainan metabolik (hiperurisemia, hiperfosfatemia, hiperkalemia) yang sering terjadi pada pasien keganasan akibat lisisnya sel-sel tumor secara cepat baik yang terjadi secara spontan ataupun karena pengobatan anti kanker. ${ }^{1-3,8-12}$ Metabolit yang dikeluarkan oleh sel-sel tumor ganas adalah asam urat, fosfor, kalium, semuanya diekskresi oleh ginjal. ${ }^{8,13}$

Makalah ini membahas tentang patogenesis dan patofisiologi, pencegahan dan tata laksana gagal ginjal akut yang sering timbul akibat metabolit tumor (asam urat, fosfat dan kalium), produk nefrotoksik akibat penghancuran/lisis yang cepat sel-sel tumor.

\section{Definisi Gagal Ginjal Akut ${ }^{14,15}$}

Gagal ginjal akut mempunyai terminologi yang khas yaitu adanya penurunan fungsi ginjal yang mendadak dengan akibat hilangnya kemampuan ginjal untuk mempertahankan homeostasis tubuh. Akibat penurunan fungsi ginjal terjadi peningkatan metabolit persenyawaan nitrogen seperti ureum $(10-20 \mathrm{mg} / \mathrm{dl} /$ 
hari) dan kreatinin $(0,5 \mathrm{mg} / \mathrm{dl} /$ hari $)$ serta gangguan keseimbangan cairan dan elektrolit yang seharusnya dikeluarkan oleh ginjal. Keadaan ini bisa disertai dengan atau tanpa oliguria. Oliguria didefinisikan sebagai jumlah air kemih yang kurang dari $240 \mathrm{ml} /$ $\mathrm{M}^{2} /$ hari atau kurang dari $0,5 \mathrm{ml} / \mathrm{kg} / \mathrm{jam} .{ }^{14,15}$

\section{Gagal ginjal akut akibat peningkatan asam urat}

Kejadian GGA akibat nefropati asam urat karena sindrom tumor lisis bisa terjadi selama perjalanan penyakit dan setelah pengobatan pasien dengan lekemia dan limfoma. ${ }^{8-12,16}$

\section{Patogenesis dan patofisiologi}

Ekskresi asam urat tampaknya lebih berkaitan dengan tipe keganasan penyakit dasar, seperti pada B sel limfoma dan leukemia. Hal ini karena pemecahan sel pada fase $S$ lebih tinggi pada limfoma sel B dan lekemia daripada pada keganasan sel T. Hasil turnover sel inilah yang mungkin merupakan alasan utama tingginya kejadian nefropati asam urat pada pasien non limfoblastik limfoma. ${ }^{17}$

Secara patofisiologi, medula ginjal, tubulus distal, dan saluran pengumpul sebagai tempat utama presipitasi asam urat dan kerusakan selanjutnya. ${ }^{7} \mathrm{Hal}$ ini karena area anatomi nefron ini merupakan daerah terjadinya konsentrasi urin maksimal dan proses asidifikasi. ${ }^{7}$ Selain itu adanya asidosis laktat akibat buruknya oksigenasi jaringan pada pasien dengan jumlah leukosit yang tinggi akan menambah deposit asam urat tersebut. ${ }^{18}$ Selanjutnya, deposit asam urat akan menyebabkan perubahan inflamasi vaskular dan berlanjut terjadi nefrosklerosis dan pielonefritis dan akhirnya terjadi gagal ginjal.?

\section{Tata laksana}

Pencegahan dan terapi nefropati asam urat akibat sindrom lisis tumor terdiri dari tiga prinsip fisika kimia, ${ }^{7-10}$ yaitu (1) hidrasi, mengalirkan cairan yang adekuat ke tubulus, (2) alkalinisasi urin, untuk meningkatkan kelarutan asam urat, dan (3) pemberian allopurinol, untuk menurunkan pembentukan asam urat.
Hidrasi diberikan secara intravena dengan cairan $5 \%$ glukosa dan 0,225\% natrium sebanyak 2-4 kali kebutuhan rumatan perhari, ${ }^{7-10}$ selama 24 jam; bila memungkinkan dapat dilanjutkan 18-45 jam sebelum pemberian kemoterapi ${ }^{19}$ untuk meningkatkan klirens asam urat dengan mencegah supersaturasi urin dari asam urat dan menyebabkan pembentukan kristal tubulus. Kelarutan asam urat selanjutnya ditingkatkan dengan alkalinisasi urin dengan memberikan natrium bikarbonat $40-100 \mathrm{mEq} / \mathrm{l}$ secara intravena untuk mempertahankan $\mathrm{pH}$ urin 6,5-7,5 dan berat jenis urin $<1,010^{\cdot 7,10,13}$ Pada $\mathrm{pH} 7,4$ lebih dari 95\% asam urat urin didisosiasi ke dalam bentuk ion yang lebih mudah larut. Alkalinisasi pada $\mathrm{pH}$ lebih dari 7,5 tidak akan meningkatkan kelarutan asam urat tapi justru mungkin akan menyebabkan alkalosis metabolik, ${ }^{15}$ pada keadaan ini bisa diberikan diuretik furosemid dosis $1 \mathrm{mg} / \mathrm{kg}$ atau mannitol $0,5 \mathrm{~g} / \mathrm{kg}$ setiap 15 menit secara intravena untuk meningkatkan keluaran urin, ${ }^{1}$ namun pada kasus oliguri hal ini merupakan indikasi kontra. ${ }^{11}$

Setelah hidrasi dan alkalinisasi segera diberikan allopurinol dengan dosis $100 \mathrm{mg} / \mathrm{M}^{2} / \mathrm{kali}$ setiap $8 \mathrm{jam}$ secara oral $1,10,19$ atau secara intravena dengan dosis 200mg/M2/hari, ${ }^{9}$ karena allopurinol dan metabolitnya yaitu oksipurinol merupakan inhibitor yang kuat terhadap xantin oksidase, enzim yang mengubah hipoxantin dan xantin menjadi asam urat. ${ }^{7-10}$ Selain itu, allopurinol mungkin mengurangi sintesis purin de novo melalui mekanisme menurunkan kadar 5fosforibosilpirofosfat melalui penghambatan fosforibosilpirofosfat aminotransferase. Berdasarkan prinsip patofisiologi ini, nefropati asam urat seharusnya dapat dicegah. ${ }^{14}$

Meskipun jarang, allopurinol dapat menyebabkan komplikasi pada ginjal. Penghambatan santin oksidase mungkin menyebabkan pembentukan batu santin dengan akibat nefropati asam urat dan gagal ginjal, ,,14 oleh karena itu perlu untuk mempertahankan $\mathrm{pH}$ urin sekitar 6,5-7,5. ${ }^{8-12}$ Kelarutan asam urat lebih besar pada $\mathrm{pH}$ urin 7,00 jadi ditekankan perlunya hidrasi urin bersama dengan alkalinisasi dan pemakaian allopurinol. Efek toksik allopurinol pada penurunan fungsi ginjal berkurang setelah obat dihentikan. Jadi penting untuk segera menghentikan pemakaian allopurinol saat remisi tercapai. ${ }^{14}$ Saat ini sebagai obat alternatif dipakai rasburicase (uricozyme) yaitu suatu bentuk rekombinan dari enzim urate oksidase, yang mengkatalisasi enzim oksidase dari asam urat menjadi allatoin, bahan yang 5 kali lebih mudah larut daripada 
asam urat. Dosis pada anak 0,20 mg/kg/hari yang dilarutkan dalam $50 \mathrm{ml}$ cairan fisiologis diberikan secara intravena selama 30 menit. ${ }^{20-21}$

Karena nefropati asam urat biasanya merupakan komplikasi akut pada terapi antitumor, tata laksana yang agresif dengan hemodialisis harus segera dilakukan, ${ }^{16}$ karena lebih efektif dibanding dialisis peritoneal. Indikasi dialisis pada pasien dengan nefropati asam urat karena sindrom tumor lisis tertera pada Tabel 1.

Tabel 1. Indikasi dialisis pada pasien dengan sindrom tumor lisis

\begin{tabular}{ll}
\hline Pemeriksaan & Kadar \\
\hline Kalium $(\mathrm{meq} / \mathrm{L})$ & $>6$ \\
Asam urat $(\mathrm{mg} / \mathrm{dl})$ & $>10$ \\
Kreatinin & $>10$ kali normal \\
Uremia & + \\
Fosfor $(\mathrm{mg} / \mathrm{dl})$ & $>10$ \\
Hipokalsemia & simtomatik \\
Hipervolemia & + \\
Hipertensi & tidak terkontrol \\
\hline
\end{tabular}

Dikutip dengan modifikasi dari Kelly KM, Lange B ${ }^{1}$

\section{GGA akibat kelebihan fosfor}

Sindrom kelebihan fosfat sering dihubungkan dengan peningkatan nyata fosfat serum dan berakibat hipokalsemia dan presipitasi deposit kalsium-fosfat didalam jantung, alveoli, kulit, jaringan subkutan, pembuluh darah kecil dan konjungtiva. ${ }^{18}$ Sepertiga pasien dengan leukemi hipokalsemik mengalami hiperfosfatemia. ${ }^{18}$

Pada anak yang menderita leukemia limfoblastik akut, hiperfosfatemia dihubungkan dengan peningkatan ekskresi fosfat di urin sebanyak $30 \mathrm{kali}^{18}{ }^{18}$ hal ini mungkin karena limfoblas mempunyai kandungan fosfat paling tinggi sekitar 4 kali dari limfosit normal. ${ }^{1,9}$

\section{Patogenesis dan patofisiologi}

Secara in vivo, kelarutan produk kalsium fosfat (Ca x P) sekitar $58 \mathrm{mg} / \mathrm{dl},{ }^{1}$ bila nilainya lebih dari $60 \mathrm{mg} / \mathrm{dl}$ terdapat peningkatan risiko presipitasi didalam mikrovaskularisasi dan tubulus ginjal. Presipitasi inilah yang akhirnya akan menimbulkan gagal ginjal akut. ${ }^{8}$

\section{Tata laksana}

Hiperfosfatemia akut karena berbagai sebab diatasi dengan mengeluarkan fosfat baik secara diet ataupun intravena dan pemberian obat-obatan pengikat fosfat. ${ }^{18}$ Kelebihan fosfat diatasi dengan hidrasi dan alkalinisasi seperti tata laksana pada hiperurisemia, dengan pemberian amfogel $30-50 \mathrm{mg} / \mathrm{kg}$ tiga kali sehari. ${ }^{10}$ Pemberian cairan infus yang mengandung $\mathrm{D}$-glukosa, asam amino esensial, dan insulin bisa membantu transport fosfat ke intraselular. ${ }^{18}$ Calcitonin bermanfaat dalam menghambat resorpsi tulang. ${ }^{18}$ Jika telah terjadi gagal ginjal oliguri diindikasikan untuk dilakukan hemodialis atau peritoneal dialisis. ${ }^{1,10,18}$

\section{GGA akibat kelebihan kalium}

Hiperkalemia sering dikaitkan dengan lisis yang cepat sel-sel tumor ${ }^{8-12}$ dan paling cepat menimbulkan kematian. ${ }^{?}$

\section{Patogenesis dan patofisiologi}

Meskipun ginjal yang normal mempunyai mekanisme proteksi untuk meningkatkan ekskresi kalium, namun mekanisme ini tidak mampu mencegah hiperkalemia yang berat dan mengancam jiwa. ${ }^{1,8}$ Ketidakmampuan fungsi ginjal ini berakibat gagal ginjal . Pasien dengan masa tumor yang besar mempunyai risiko yang tinggi karena kemoterapi akan menyebabkan lisis cepat selsel tumor. ${ }^{8-12}$ Hiperkalemia ditemukan pada kasus peningkatan asam urat dan fosfat inorganik. Risiko hiperkalemia meningkat dengan adanya nefropati asam urat. $^{8,9}$

\section{Tata laksana ${ }^{1,8,9}$}

a. Hindari semua diet yang mengandung kalium

b. Hidrasi dan alkalinisasi seperti pada tata laksana hiperurisemia

c. Kayexalate $1 \mathrm{~g} / \mathrm{kg} /$ dosis setiap 6 jam secara oral atau melalui pipa nasogastrik

d. Jika konsentrasi kalium serum $>=7 \mathrm{meq} / \mathrm{L}$ :

- insulin 0,1 unit $/ \mathrm{kg} / \mathrm{jam}$ dengan glukosa 0,5 $\mathrm{g} / \mathrm{kg} / \mathrm{jam}$ secara infus kontinu

- hemodialisis atau peritoneal dialisis 


\section{Ringkasan}

Gagal ginjal akut merupakan komplikasi yang sering pada penyakit keganasan hematologi maupun tumor ganas padat. Terdapat berbagai penyebab yang mendasari terjadinya gagal ginjal akut tersebut salah satunya adalah akibat produk/metabolit tumor yang bersifat nefrotoksik yang dikeluarkan oleh tumor atau akibat penghancuran cepat sel-sel tumor. Beban metabolit yang berlebihan tersebut akhirnya akan mengganggu laju filtrasi glomerulus dan kerusakan tubulus dengan akibat lanjut terjadi gagal ginjal. Pencegahan dan tata laksana gagal ginjal akut pada penyakit keganasan anak tergantung pada faktor penyebabnya. Oleh karena itu diperlukan pengenalan dini agar segera dapat diatasi dengan cepat karena gagal ginjal akut lebih mudah dicegah daripada diobati.

\section{Daftar Pustaka}

1. Kelly KM, Lange B. Oncologic emergencies. Pediatic Clin North Am 1997; 274: 809-30.

2. Lanore JJ, Brunet F, Pochard F. Hemodialysis for acute renal failure in patients with hematologic malignancies. Critical Care Medicine 1991; 19: 346-51.

3. Stapleton FB, Strother DR, Roy S, Wyatt RJ, McKay CP, Murphy SB. Acute renal failure at onset of therapy for advanced stage Burkitt limphoma and B cell acute lymphoblastic lymphoma. Pediatrics 1988; 82: 8639.

4. Foerster J. Multiple myeloma. Dalam: Lee GR, Bithell TC, Foerster J, Athens JW, Lukens JN, Penyunting. Wintrobe's clinical hematology. Edisi ke-9. Philadelphia: Lea \& Febiger; 1993. h. 2219-40.

5. Sodeman WA, Sodeman TM. Multiple mieloma. Dalam: Joko S, penyunting. Sodeman Patofisiologi. Edisi ke-7. Jilid II. Jakarta: Hippocrates; 1991. h. 289-91.

6. Kher KK. Evaluation of renal functions. Dalam: Kher KK, Makker SP, Penyunting. Clinical Pediatric Nephrology. Singapore: McGraw-Hill; 1992. h. 3-22.

7. Rauf S. Nefropati toksik. Dalam: Alatas S, Tambunan T, Trihono PP, Penyunting. Buku ajar Nefrologi Anak jilid 2. Jakarta: Balai Penerbit Fakultas Kedokteran Universitas Indonesia; 1996. h. 415-25.

8. Lange B, Junior JAO, Goldwein JW, Packer RJ, Ross AJ. Oncologic emergencies. Dalam: Pizzo PA, Poplack DG, penyunting. Principles and practice of pediatric oncology. Edisi ke-3. Philadelphia: Lippincott; 1997. h. 1025-46.

9. Tumor lysis syndrome. Didapat dari: URL: http:// www.emedicine.com/ped/topic2328. htm

10. Lanzkowsky P, penyunting. Manual of pediatric hematology and oncology. Edisi kedua. United States of America: Churchill Livingstone; 1995. h. 579-83.

11. Oncologic emergencies. Didapat dari: URL: http:// www.vnh.org/pediatric Emergencymanual/oncologic.html.

12. Pinkerton $\mathrm{CB}$ Emergencies and supportive care. Dalam: Pinkerton CB, Cushing P, Sepion B. A practical handbook childhood cancer management. London; Chapman \& Hall ; 1994. h. 203-11.

13. Garnick MB, Mayer RJ. Management of acute renal failure associated with neoplastic disease. Dalam: Yarbro JW, Bornstein RS, penyunting. Oncologic emergencies. New York: Grune \& Stratton; 1986. h. 247-71.

14. Bock GH. Acute renal failure. Dalam: Kher KK, Makker SP, Penyunting. Clinical Pediatric Nephrology. Singapore. McGraw-Hill; 1992. h. 469-97.

15. Yoel C. Pengelolaan gagal ginjal akut pada anak. Simposium Nasional Nefrologi Anak ke-5 dan simposium Nasional Pediatri Gawat Darurat ke-2; Medan, Sumatera utara; 1992.

16. Andreoli SP, Clark JH, McGuire WA, Bergstein JM. Purine excretion during tumor lysis in children with acute lymphocytic leukemia receiving allopurinol: relationship to acute renal failure. J Peditr 1986; 109:2928.

17. Shad A, Magrath I. Malignant non Hodgkin's lymphomas in children. Dalam: Pizzo PA, Poplack DG, penyunting. Principles and practice of pediatric oncology. Edisi ke-3. Philadelphia: Lippincott; 1997. h. 54587.

18. Moorthy AV, Chesney RW. Renal and metabolic effects of extrarenal neoplasms. Dalam: Edelmann CM, Bernstein J, penyunting. Pediatric Kidney disease. Edisi ke-2. Boston: Little Brown; 1992. h. 1557-68.

19. Baldree LA, Stapleton FB. Uric acid metabolism in children. Pediatric Clin North Am 1990; 37:391-418.

20. Goldman SC, Holcenberg JS, Finklestein JZ, dkk. A randomised comparison between rasburicase and allopurinol in children with lymphoma or leukemia at high risk for tumor lysis. Blood 2001; 97:29983003.

21. Pui CH, Mahmoud H, Wiley JM. Recombinant urate oxidase for the prophylaxis or treatment of hyperuricema in patient with leukemia or lymphoma. J of Clin Oncology 2001; 19:697-704. 